\title{
Lembrança \\ de Ítalo Bettarello
}

\section{ALFREDO BOSI}

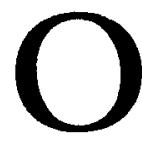

professor Bettarello começava seus cursos de primeiro ano pedindo aos alunos das Letras Neolatinas que reparassem nos plátanos da Praça da República. Porque os plátanos, como todas as coisas belas deste mundo, só existem depois que a nossa atençăo despertou para elas. Era a primeira e maior lição: "Abram os cinco sentidos para a vida, como a rosa abre as pétalas para o sol e a chuva". O conselho parecia simples, mas como provamos a cada passo a sua dificuldade! $\mathrm{O}$ abstrato $\mathrm{o}$ incomodava, no fundo ele $\mathrm{o}$ temia, pois atrás das idéias gerais vêm, com monótona freqüência, a rigidez, o preconceito, o fanatismo e, perda maior, a obtusidade diante da obra de arte.

O remédio para esses males todos estava em recuperar os olhos, os ouvidos e o tacto, sobretudo o tacto. "Como é possível - dizia entender uma escultura de Michelangelo sem tocar, apalpar, apertar a matéria torneada pela mão do homem?" As suas mãos brandas, mas firmes, exploravam o mundo. Segui-lo pelas ruas da cidade era receber uma lição de coisas: detinha-se, sem pressa, diante dos antúrios gigantes, dos tinhorōes, dos guaimbês da Praça; fazia-me parar em frente de uma vitrine de pedras brasileiras a distinguir brilhos, tonalidades, formatos; e uma loja de artefatos de camurça na Avenida Ipiranga era uma festa para seus sentidos, festa que ele queria logo compartilhada.

Das viagens à Itália guardava fielmente a memória das sensaçóes. Fésole era o convento em que os frades do Poverello subiam e desciam as escadas avermelhadas cantando madrigais da Renascença; de Pestum evocava menos as clássicas ruínas que a imagem de um pastor que por elas passeava com suas ovelhas, e podia ignorar a História porque se confundia com dois mil anos de civilizaçáo.

Esse conhecer pelos sentidos, que é uma das vertentes centrais da estética italiana, e que reponta até na mente escolástica de um Tomás de Aquino (pulchrum dicitur quod visum placet: belo diz-se o que, visto, agrada) fazia de Ítalo Bettarello um leitor herético de Croce (San Benedetto Croce!), lido por um viés todo seu que acabava minando a aura idealizante que envolve, no filósofo, os grandes termos de intuição e sentimento. 
Desses conceitos só lhe importavam as notas concretas, sensíveis: a potência da imagem, a euforia do ritmo, o impacto da sonoridade. E aqui o elenco das leituras que lhe devemos, seus alunos que fomos, é assunto longo e variado. $O$ exemplário começaria com as assonâncias medievais do Cântico do Irmão Sol de São Francisco de Assis para acabar nos fragmentos cósmicos do seu poeta, Ungaretti, passando pelos cantos carnavalescos de Lorenzo de Médici (com que arroubo lia:

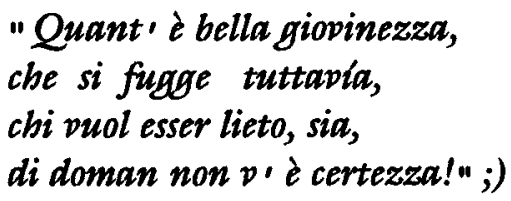

pelos sonetos mais densamente metafóricos do Cavalier Marino (quanto de poética barroca nos deu a ler, e com que inocente prazer fazia despique à crítica universitária francesa quando nos mostrava que Racine, o intocável, o olímpico Jean Racine, foi bem barroco em Phèdre, e ali estava Leo Spitzer, o crociano Spitzer para prová-lo); por Leopardi (como fará falta agora quem leia com tanta paixão $L$ infinito e o final divino do Cantico del Gallo Silvestre!); pelos futuristas (e aqui ensinava o que para muitos foi ovo de Colombo: a derivação futurismo-concretismo...). E a sua tese, ainda inédita, de láurea, defendida em Turim, foi uma das primeiras visóes orgânicas da poesia italiana deste século.

Perdão, mestre Bettarello, se falo pela rama, per schizzi, abbozzi, spunti ... A rigor, o legado se abriria em tantas direçōes! Conheci, pela tua máo, a lógica implacável de Maquiável, a fantasia especulativa de Vico, a esté.ica da forma de Pareyson, a quem Eco tanto deve; e, no momento em que todos os existencialistas eram foscos e trágicos, soube da categoria da possibilità que o existencialismo de Abbagnano quis salvar, no mais escuro da Guerra, do naufrágio certo de todas as esperanças. O que era ainda uma centelha despedida pelo pensamento da Renascença, tal como se define naquele texto de Pico della Mirandola que nấo te cansavas de nos repetir:

"Dio ha detto all' uomo: - Non ti
bo fatto né celeste né terrestre no perché
tu ti foggiassi da te; potrai degenerare
perso i bruti, potrai rigenerarti fino
alb altezza delle cose dipine" (Náo te
fiz nem celeste, nem terreno, para que
te forjasses por ti mesmo...).

A cultura de um homem culto não é uma coisa inocente. Mexe com tudo. Ítalo Bettarello entrava penosamente nas roupas apertadas da 
instituição. Antes e depois da longa doença. A sua aversão a aulas com hora marcada tinha raízes em um sentimento do tempo muito parecido com o dos revolucionários de $\mathbf{4 8}$ que começaram as suas manifestaçôes de protesto atirando contra o relógio da torre de Notre Dame. As revoluçóes ainda náo venceram, mas os relógios se multiplicaram; e com eles os títulos, os papéis, as hierarquias, as carreiras, às carreiras. O homem que admirava o estilo de aço do Príncipe não dava um passo para adiantar-se na política dos pequeninos meios que se soem justificar com altos fins. "Bettarello - dizia-lhe, impaciente, o amigo Bizzarri - hás de ser sempre o primeiro a conceber e o último a realizar". Mas a alegria está na concepçáo. O resto é uma defesa miúda e dolorosa.

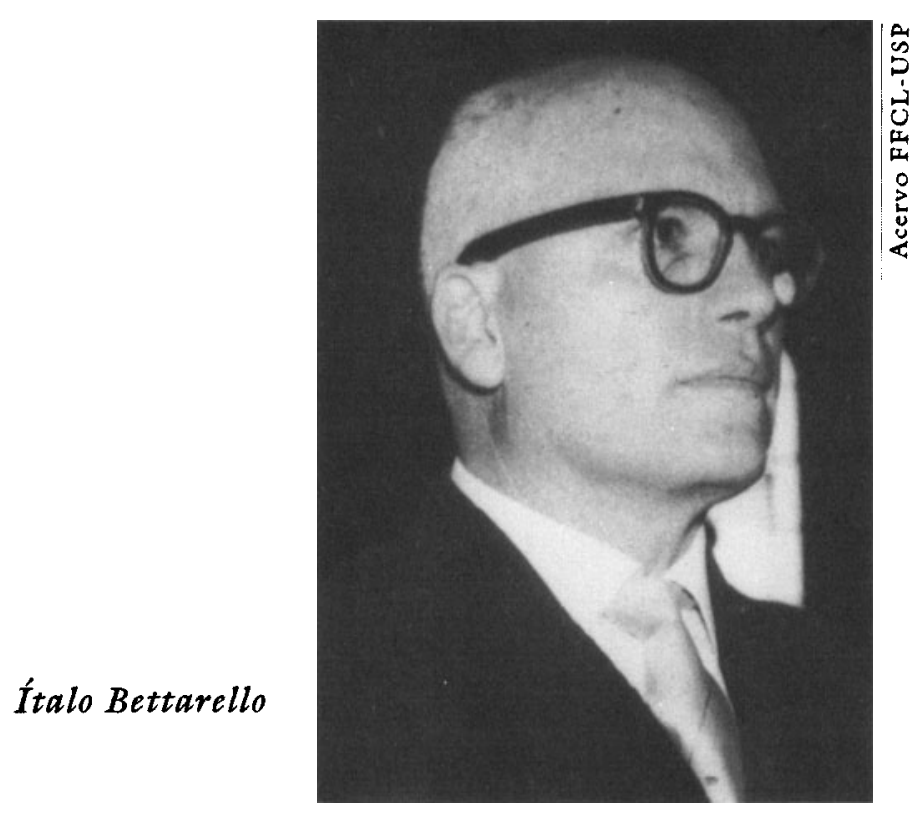

Havia nele uma resistência inata a esse processo de julgar, sumário e mecânico, com que se văo tomando, hoje em dia, decisóes dentro e fora da vida universitária. Quem amava a beleza e a dignidade do corpo sabia que é preciso esperar pelo crescimento dos seres, pela sua difícil maturação, e suportar com paciência as mazelas que advêm da nossa comum fragilidade. Por quase vinte anos, eu o vi defendendo o semelhante, pensando nos casos particulares (ao contrário dos que odeiam toda exceçáo como se tivessem descoberto onde está a norma), e buscando conservar nas relaçóes de trabalho um calor e uma immediatezza que o leviatã burocrático torna hoje quase inviável.

A sua retidão conhecia razóes maiores que as da régua e do com- 
passo. E nos labirintos da vida prática, quando é preciso afinal ter algum critério, alguma lei, para atinar com o certo ou o errado, o justo, ou o injusto, ele agia como se fizesse sua afirmaçáo de Ugo Foscolo, poeta: "Fora da compaixão todas as virtudes são usurárias".

Alfredo Bosi é professor de Literatura Brasileira da Faculdade de Filosofia, Letras e Ciéncias Humanas da USP e editor da revista Estrudos Averengados.

Texto extraido do Boletim no 15 (Nova Serie) - talo Betwarello - A poesia italiana atual (Departamento de Letras Modernas 3, Curso de Itrliano 1, 1977, pp. 135-37. Traduçáo, notas e apresentaçăo de Elvira Rina Malerbi Ricci). 